\title{
Indicators of climate change in agricultural systems
}

\author{
Jerry L. Hatfield ${ }^{1}$ (D) John Antle ${ }^{2}$ - Karen A. Garrett ${ }^{3}$. \\ Roberto Cesar Izaurralde ${ }^{4,5}$. Terry Mader $^{6}$. \\ Elizabeth Marshall ${ }^{7}$. Mark Nearing ${ }^{8}$. \\ G. Philip Robertson' ${ }^{9}$ Lewis Ziska ${ }^{10}$
}

Received: 17 December 2016 / Accepted: 13 May 2018/Published online: 6 June 2018

(C) The Author(s) 2018

\begin{abstract}
Climate change affects all segments of the agricultural enterprise, and there is mounting evidence that the continuing warming trend with shifting seasonality and intensity in precipitation will increase the vulnerability of agricultural systems. Agricultural is a complex system within the USA encompassing a large number of crops and livestock systems, and development of indicators to provide a signal of the impact of climate change on these different systems would be beneficial to the development of strategies for effective adaptation practices. A series of indicators were assembled to determine their potential for assessing agricultural response to climate change in the near term and long term and those with immediate capability of being implemented and those requiring more development. The available literature reveals indicators on livestock related to heat stress, soil erosion related
\end{abstract}

This article is part of a Special Issue on "National Indicators of Climate Changes, Impacts, and Vulnerability" edited by Anthony C. Janetos and Melissa A. Kenney.

Jerry L. Hatfield

jerry.hatfield@ars.usda.gov

1 National Laboratory for Agriculture and the Environment, USDA-ARS, Ames, IA, USA

2 Oregon State University, Corvallis, OR, USA

3 Plant Pathology Department, Institute for Sustainable Food Systems, and Emerging Pathogens Institute, University of Florida, Gainesville, FL, USA

4 Department of Geographical Sciences, University of Maryland, College Park, MD, USA

5 Research Professor Texas Agrilife, Texas A\&M University, College Station, TX, USA

6 University of Nebraska, Lincoln, NE, USA

7 Economic Research Service, Washington, DC, USA

8 USDA-ARS, Tucson, AZ, USA

9 Kellogg Biological Station, Michigan State University, Lansing, MI, USA

10 USDA-ARS, Beltsville, MD, USA 
to changes in precipitation, soil carbon changes in response to increasing carbon dioxide and soil management practices, economic response to climate change in agricultural production, and crop progress and productivity. Crop progress and productivity changes are readily observed data with a historical record for some crops extending back to the mid-1800s. This length of historical record coupled with the county-level observations from each state where a crop is grown and emerging pest populations provides a detailed set of observations to assess the impact of a changing climate on agriculture. Continued refinement of tools to assess climate impacts on agriculture will provide guidance on strategies to adapt to climate change.

\section{Introduction}

Climate change impacts all sectors of the natural and human ecosystem; however, climatic impacts on the basic human needs of water and food are among the most threatening. Food security depends upon our ability to adapt agricultural systems to climate change. Agricultural systems represent the ability to efficiently produce food, feed, and fiber, and disruptions due to climate change impact our capability to feed the future world population. Agricultural systems are multi-faceted and complex because of the range of plant and animal commodities affected by the interactions between climate and management. This agricultural social ecosystem system described by Walthall et al. (2012) defined linkages among decision making components driven by the perceptions of risk, personal experience and preferences, knowledge of production capacity of the system, and a multitude of external factors, e.g., market demand, government policies, climatic variation, and land tenure. Coupling these linkages with the uncertainty of the impact of climate change on agricultural systems requires a robust methodology for indicators of the agricultural system in response to climate. Recent climate assessments (e.g., Melillo et al. 2014) incorporate agriculture as one of the key sectors impacted by climate change, and these assessments highlight many of the components vulnerable to climate change and require robust indicators to determine if the impact is increasing and our food and natural resource security is at risk. The goal of this paper is to integrate a conceptual model of climate interactions with agricultural systems to identify potential indicators and indicators currently available and those requiring more development in order to provide a robust methodology for future assessments. The approach the group utilized was to assess different indicators relative to the ability to quantify the impact of climate change on different segments of the agricultural system.

\section{Concepts of agricultural systems and climate change}

Agricultural systems represent the primary linkage between the climate system and production from grasslands, crops, or livestock (Fig. 1). The direct linkages among these components and climate have been summarized in recent articles by Hatfield et al. (2011), Izaurralde et al. (2011), and Walthall et al. (2012). In this conceptual diagram, climate regulating services, e.g., temperature, carbon dioxide, solar radiation, or precipitation, directly impact grassland, cropping systems, livestock production, and pest dynamics. Precipitation directly affects water supply because of the feedback through the evaporation process which returns water vapor to the climate system (Fig. 1). The water cycle is a critical part of agricultural systems, and variation in precipitation governs the amount of water available to the grassland or cropping 
system. Variation in water availability is direct related to variability in production and is tempered by variation in temperature (Hatfield et al. 2011; Izaurralde et al. 2011). Linkages and feedbacks among the components in the conceptual diagram encompass the direct effects of climate on production and pests and the indirect effects induced by societal demands on ecosystem services and responses to energy and food production (Fig. 1). In this analysis, we evaluated potential indicators using this framework and considered such factors as the changes in the length of the growing season, onset of spring, chilling hours over the winter, and increased heat stress for livestock. We also considered the potential for mitigation of $\mathrm{CO}_{2}$ and greenhouse gases under soil carbon dynamics as a link between adaptation and mitigation strategies. One of the critical feedbacks to the climate system is the release of greenhouse gases into the atmosphere; mitigation strategies to increase soil carbon sequestration will increase the resilience of agricultural systems to climate stressors (Walthall et al. 2012). There were several potential indicators considered in the course of this effort, and the ones shown here encompass those representing a direct linkage to climate and the interactions shown in Fig. 1. Indicators meeting these criteria and assessed for their potential as viable indicators to detect agricultural response to climate change are described in Table 1.

\section{Candidate indicators}

\subsection{Livestock heat stress}

Livestock are impacted by climate change, and the potential occurrence of extreme temperature events can disrupt the ability of animals to produce. Economic losses from reduced performance of livestock experiencing severe environmental stress exceed losses associated

A. Climate regulating services

B. Evaporation

C. Wastewater and runoff

D. Irrigation water
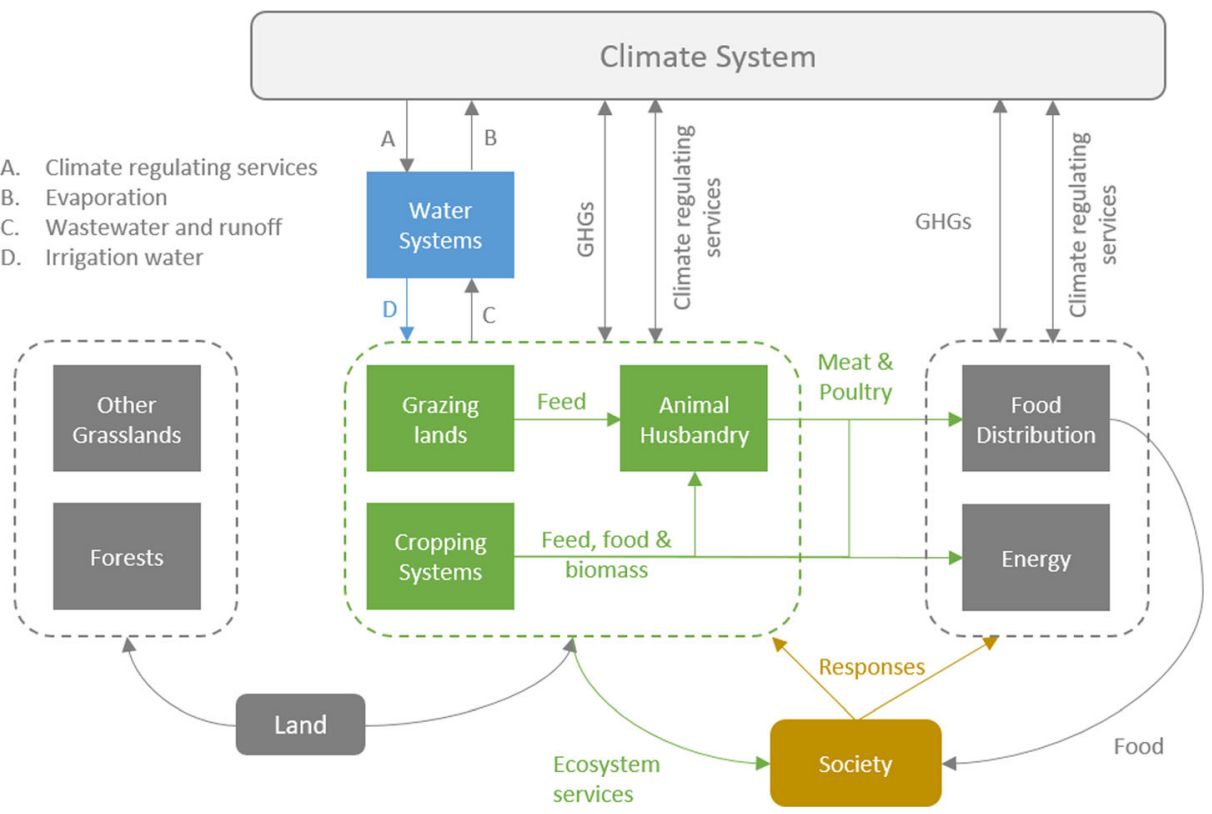

Fig. 1 Conceptual diagram of potential indicators of climate impacts on agricultural systems 
Table 1 Indicators for agricultural response to climate change

\begin{tabular}{|c|c|c|c|}
\hline $\begin{array}{l}\text { Agricultural } \\
\text { component }\end{array}$ & Climate factor & Impact on agricultural system & Indicator \\
\hline Livestock & Extreme cold/heat events & Lost productivity, mortality & $\begin{array}{l}\text { Annual sum of } \\
\text { temperature-humidity index } \\
\text { values and wind chill index } \\
\text { values for a given location }\end{array}$ \\
\hline Livestock & Extreme climate events & Lost productivity, mortality & $\begin{array}{l}\text { Annual sum of comprehensive } \\
\text { climate index for a given } \\
\text { location }\end{array}$ \\
\hline Soil & Intense rainfall events & $\begin{array}{l}\text { Soil erosion and loss of topsoil, } \\
\text { nutrient runoff }\end{array}$ & $\begin{array}{l}\text { Increase in } \mathrm{R} \text { value, rainfall } \\
\text { intensity }\end{array}$ \\
\hline Soil & $\begin{array}{l}\text { Carbon sequestration, } \\
\text { greenhouse gas exchange }\end{array}$ & $\begin{array}{l}\text { Soil quality, water infiltration, } \\
\text { nutrient cycling, soil } \\
\text { aggregation, carbon } \\
\text { sequestration }\end{array}$ & Organic carbon changes \\
\hline Soil & Precipitation & $\begin{array}{l}\text { Soil water content and } \\
\text { infiltration }\end{array}$ & $\begin{array}{l}\text { Water availability for plant } \\
\text { production }\end{array}$ \\
\hline Plants & Temperature & Phenological development & $\begin{array}{l}\text { Changes in onset of } \\
\text { phenological development, } \\
\text { e.g., bud break, first flower }\end{array}$ \\
\hline Plants & Temperature & $\begin{array}{l}\text { Chilling hours for perennial } \\
\text { plants }\end{array}$ & $\begin{array}{l}\text { Sufficient exposure to } \\
\text { temperatures below a species } \\
\text { specific threshold to induce } \\
\text { flowering }\end{array}$ \\
\hline Plants & Temperature & $\begin{array}{l}\text { Growing degree days and plant } \\
\text { development, phenology, } \\
\text { average annual minimum } \\
\text { temperature }\end{array}$ & Plant hardiness zone map \\
\hline Plants & $\begin{array}{l}\text { Temperature, precipitation, } \\
\text { and } \mathrm{CO}_{2}\end{array}$ & $\begin{array}{l}\text { Gross and net primary } \\
\text { productivity }\end{array}$ & Productivity of ecosystems \\
\hline Plants & $\begin{array}{l}\text { Temperature, precipitation, } \\
\text { and } \mathrm{CO}_{2}\end{array}$ & Yield, biomass & $\begin{array}{l}\text { Productivity and economic } \\
\text { return of crop production } \\
\text { systems }\end{array}$ \\
\hline Pests & Temperature and humidity & $\begin{array}{l}\text { Increased insect or diseases } \\
\text { pressures }\end{array}$ & $\begin{array}{l}\text { Shifting ranges and populations } \\
\text { of insects and diseases }\end{array}$ \\
\hline Pests & $\begin{array}{l}\text { Temperature and } \\
\text { precipitation }\end{array}$ & Increased weed pressures & Invasive weed distribution \\
\hline Economics & $\begin{array}{l}\text { Extreme events in } \\
\text { temperature and } \\
\text { precipitation }\end{array}$ & $\begin{array}{l}\text { Loss of productivity, crop, or } \\
\text { livestock losses }\end{array}$ & $\begin{array}{l}\text { Crop or livestock insurance } \\
\text { claims and indemnities }\end{array}$ \\
\hline
\end{tabular}

from cattle death by 5- to 10-fold (Mader 2012). Each year, environmental heat stress alone costs the dairy industry over $\$ 900$ million and beef and swine industry over $\$ 300$ million (St. Pierre et al. 2003). Exposure to heat stress has a large impact on livestock performance and well-being. Moisture and heat content of the air, thermal radiation, and airflow impact total heat exchange between the atmosphere and an animal. Thus, the effective, or apparent, temperature that an animal responds to is a combination of environmental variables. In the case of humans, the useful effect is the sensation of comfort; for animals, this effect is on performance, health, and well-being. Indices, because they combine several environmental components, are much more robust for characterizing environmental effects on animal productivity and well-being. To overcome the shortcomings of using ambient temperature as the only indicator of animal stress, thermal indices have been developed to better characterize the influence of multiple environmental variables on the animal. The temperature-humidity index 
(THI) has been extensively applied in moderate to hot conditions, even with recognized limitations related to airspeed and radiation heat loads. For cold conditions, the wind-chill index (WCI), relating air temperature and wind speed to the time required for freezing a small cylinder of water, serves as a rough guide for measuring cold stress.

These indices are only relevant under either hot or cold conditions, but not both, because simpler indices do not incorporate major environmental components experienced over a range of hot or cold conditions. In addition, appropriate environmental stress thresholds are needed that are flexible and measure stress levels based on environmental conditions, management practices, and physiological status. Mader et al. (2010) developed the comprehensive climate index (CCI) and comparable thresholds utilizing multiple environmental variables that are incorporated into a continuous index. The CCI incorporates relative humidity, wind speed, and solar radiation to produce an "apparent temperature" that adjusts ambient temperature (Ta) for the effects of environmental variables.

Aside from the benefits of obtaining an apparent temperature for assessing comfort level, climate change effects on livestock can now be assessed over a large range of environmental conditions utilizing the CCI. Physiological and metabolic responses can also be better assessed based on apparent temperature. For strategic decision-making, the CCI can be applied across various life stages and species, in order to maximize the utility of probability information. Multi-factor indices are needed that are comprehensive in nature, which allow for greater application across a range of conditions and have potential for use in assessing environmental effects on animal health, welfare, and productivity. Increased probabilities of extreme events and the impact on livestock productivity increase the potential use of an indicator capable of quantifying the extent of disruption in livestock production. Annual sums of the THI, WCI, or CCI serve as an indicator of the changing environment for livestock for a given location.

\subsection{Soil erosion and land use}

Soils are a foundation for agricultural production, and soil erosion through water or wind erosion reduces the capacity of the land to efficiently produce feed, food, or fiber. Several processes, both natural and anthropogenic, degrade soils. These processes include erosion, compaction, salinization, toxification, and loss of organic matter. Of these, soil erosion is most directly impacted by climate change and the most pervasive. Excessive rates of erosion decrease soil productivity, increase loss of soil organic carbon and nutrients, and reduce soil fertility.

Soil erosion rates respond to climate change for a variety of reasons, including climatic effects on plant biomass production, plant residue decomposition rates, soil microbial activity, evapotranspiration rates, soil surface sealing and crusting, and shifts in land use necessary to accommodate a new climatic regime (Williams et al. 1996). However, the most consequential effect of climate change on water erosion will be in changes in erosive power, or erosivity, of rainfall. Studies using erosion simulation models show that erosion response is much more sensitive to the rainfall amount and intensity than other environmental variables (Nearing et al. 1990). Warmer atmospheric temperatures associated with greenhouse warming are expected to lead to a more vigorous hydrological cycle, including more extreme, and hence erosive, rainfall events (Kundzewicz et al. 2007). Atmosphere-Ocean Global Climate Models also indicate potential changes in rainfall patterns, with changes in both the number of wet days and the percentage of precipitation coming in intense convective storms as opposed to longer duration, less intense storms. Daily rainfall amounts have increased across much of the USA 
over the last century, as measured by the percentage of rainfall that falls in heavy ( $>95$ th percentile) and very heavy (>99th percentile) events (Soil and Water Conservations Society 2003). Increasing heavy downpours, as defined by greater than 1.25 in., has also been observed in Iowa (Walthall et al. 2012).

Rainfall erosivity is correlated to the product of total rainstorm energy and maximum 30 min rainfall intensity during a storm (Wischmeier and Smith 1978). The relationship first derived by Wischmeier and Smith has proved to be robust and is still used today in the Revised Universal Soil Loss Equation (Renard et al. 1997), which is the current technology applied in the USA for conservation planning and compliance. Studies using a physically based, continuous simulation model of erosion have also substantiated the geographic trends of published R-factors for several parts of the USA (Baffaut et al. 1996).

A direct computation of the rainfall erosivity factor, R, for the RUSLE model requires longterm data for rainfall amounts and intensities. Precipitation rate data at the hourly time interval is archived by the National Centers for Environmental Information (www.ncei.noaa.gov) and provides monthly and annual total precipitation across the USA to estimate rainfall erosivity. Increases in rainfall intensity and total rainfall may not remain consistent under climate change and care will be required when using these relationships.

Renard and Freimund (1994) evaluated erosivity at 155 locations within the continental USA and developed statistical relationships between the R-factor and total annual precipitation at the location and a coefficient calculated from monthly rainfall amounts. These relationships have been used to estimate rainfall erosivity changes in response to projected future rainfall changes (Nearing 2001). An annual calculation of $\mathrm{R}$ based on precipitation data could be used to track changes in rainfall erosivity across the USA. If both rainfall amount and intensity were to continue to change together in a statistically representative manner as they exhibit under current observations, assuming temporally stationary relationships between amounts and intensities, predicted erosion rate would increase on the order of $1.7 \%$ for every $1 \%$ increase in total annual rainfall (Pruski and Nearing 2002). There is an increasing concern that current conservation practices may not be sufficient to ensure that the soils are protected from excessive erosion and further degradation is reduced (Garbrecht et al. 2015).

\subsection{Soil organic matter changes}

Soil organic carbon, a key indicator of ecosystem productivity and health, is affected by abiotic and biotic factors. Soil organic carbon monitoring in agricultural fields can serve as an indicator of how agriculture might be affected by climate variability and change and how these effects and changes affect carbon reservoirs as part of mitigation strategies. However, differentiating the interacting effects of climate and management has proven difficult.

We propose a two-pronged approach to use soil carbon as an indicator. An integrated approach outlined by Brown et al. (2010) to monitor soil organic carbon over large areas combines remote sensing, modeling, and soil sampling technologies with agricultural databases. This approach estimates soil carbon changes locally and regionally with the variation partitioned into climate vs. technology change.

The approach envisions periodic measurements of soil carbon and other soil properties as well as the monitoring of agricultural practices. These measurements and monitoring activities would be implemented along the flight path of systems equipped with airborne (e.g., AVIRIS) or (eventually) satellite-based (HyspIRI) hyperspectral remote sensing technologies. A variety of plant growth and surface characteristics could be detected using these technologies such as 
vegetation indices, biomass, LAI, chlorophyll, residue cover, and albedo. Remote sensing and field data can be used to test/improve crop and land-surface parameterizations. Soil carbon and other properties would be monitored at different time and spatial intervals (daily, weekly, monthly, yearly). Microsite testing approaches and hierarchical sampling planning should be considered for crop and soil monitoring.

The second approach utilizes observations of soil carbon at well-documented benchmark sites, where consistent management over decades provides a means to observe change driven primarily by climate. Coupling these changes with estimates of soil carbon change derived from biogeochemical crop models will allow changes in technology (including crop genomics, tillage, and fertilization) to be factored out. MODIS remote sensing products could then allow changes to be scaled via modeling to larger regions. Sites would be located at long-term research sites such as those located in IL, OH, MO, OR, and MI (Paul et al. 1997) and identified from emerging agricultural networks such as GRACEnet (Greenhouse Gas Reduction through Agricultural Carbon Enhancement), LTAR (Long-term Agroecological Research Network), and AgMIP (Agricultural Model Intercomparison and Improvement Project). Agricultural Ameriflux sites in IL, IA, MI, TX, and TN will facilitate calibration of the simulation models.

The first approach requires the implementation of a multi-year, multi-site pilot project utilizing an integrated use of technologies capable of monitoring soil carbon changes. Examples of these technologies include remote sensing of vegetation and surface conditions, modeling plant growth, water balance, and nutrient dynamics. The second approach utilizes the Natural Resource Inventory (NRI) to identify a set of well-documented sites at which soil carbon can be observed under management conditions that change slowly and with wellunderstood effects on soil carbon. The veracity of models that predict the effects of management for each site will need to be evaluated to determine the accuracy of these models. There is a need for a thorough assessment of soil carbon; however, this indicator requires further development and evaluation before implementation.

Carbon exchanges are not isolated to changes in soil carbon and one indicator with potential value to assess the changes in the land surface is the gross or net primary productivity. These methods are based on either direct measurements of the carbon fluxes over different surfaces using micrometeorological techniques (e.g., Ameriflux, OzFluz) or indirect estimates via remote sensing methodologies (Gitelson et al. 2012, 2015). These hold promise as direct methods to measure the impact of climate change on a large scale and require additional assessment of this indicator in response to climate change variables.

\subsection{Economic impacts of climate change on agricultural systems}

Climate change projections suggest an increase in winter and spring precipitation across the northern USA and an associated increase in the incidence of extreme weather events (Melillo et al. 2014). One measure of the potential economic impacts of such extreme events within the agricultural sector, as well as an indicator of whether such impacts are increasing as climate conditions change, could be derived from crop insurance claims and payouts. While crop insurance can cover a number of crop impacts, including hurricanes, hail, and pest damage, the claims from agricultural production most directly linked to extreme events are those related to drought, flooding, or excess moisture/precipitation/rain. One potential indicator of the magnitude and direction of change of agricultural impacts of extreme events would be fraction of total indemnities paid out for drought, flood, and excessive wetness (Walthall et al. 2012). 
Developing indicators related to the change in the distribution of indemnities provide a quantitative measure of the effect of changing climate; however, not all commodities are crop insurance eligible, so the economic impact is more difficult to assess.

\subsection{Crop progress and productivity}

Production of food from crops and livestock is necessary to sustain life, and the continual need to produce more food on a global basis to feed the expanding world population increases the potential impact of disruption in production and food security. These projections of food production do not account for the disruptions attributable to climate change and the indirect effects from increasing insect, disease, and weed pressure. Impacts of climate change on plant production can be summarized as being positive under the effects of increasing carbon dioxide $\left(\mathrm{CO}_{2}\right)$, negative with effects of increasing temperatures, and variable from precipitation timing and amounts (Hatfield et al. 2011; Walthall et al. 2012). The effect of increasing $\mathrm{CO}_{2}$ on plant productivity is generally positive with enhanced production and improved water use efficiency (Hatfield et al. 2011). Projections of temperature increase showed a large range in crop productivity with estimates of around $5 \%$ with temperature increases of $1{ }^{\circ} \mathrm{C}$ (Schlenker and Roberts 2009; Hatfield et al. 2011) to over 50\% in maize and soybean under extreme warming (Schlenker and Roberts 2009; Hatfield 2016). Rising temperatures increase the rate of phenological development and reduced productivity because of the shortened growth cycle (Hatfield et al. 2011). A portion of the productivity impact can be related to the vulnerability of the pollination stage to extreme temperatures because of the sensitivity of the pollen to dehydration under high temperatures (Hatfield et al. 2011).

Effect of increasing temperatures on plant growth has been evaluated through the use of crop simulation models and statistical analyses. Lobell and Field (2007) showed maize yields decreased $8.3 \%$ per $1{ }^{\circ} \mathrm{C}$ rise without any water stress. Asseng et al. (2015) used 30 different wheat models to simulate wheat production and concluded grain production would decrease $6 \%$ per $1{ }^{\circ} \mathrm{C}$ rise and become more variable in space and time. The projections for wheat by Asseng et al. (2015) are similar to the $5.3 \%$ yield reduction per $1{ }^{\circ} \mathrm{C}$ observed in Australia by Innes et al. (2015) using a combination of experimental results coupled with simulation models. There is a differential response of plants to temperature throughout the growth cycle, and the recent results by Laza et al. (2015) for rice showed that high night temperatures had no effect during the vegetative stage; however, high nighttime temperatures during the reproductive stage reduced yields because of the increased dark respiration rate and spikelet degeneration. This is similar to the results of Hatfield and Prueger (2015) and Hatfield (2016) from their controlled environment studies with high nighttime temperatures (plus 3C above normal temperatures) on maize yield which showed reductions of over $50 \%$ in maize grain yield.

Warming temperatures decreased USA wheat yields as observed by Tack et al. (2015) using historical yield trials and meteorological data for Kansas. They used a combination of freezing and warming impacts in their regression model to evaluate yield trends and variation among years. Their results showed a potential $40 \%$ reduction in wheat yields with a $4{ }^{\circ} \mathrm{C}$ temperature increase and that newer varieties were less able to resist heat stress above $34{ }^{\circ} \mathrm{C}$ than older varieties. They suggested that selection of newer varieties by producers to offset climate impacts may not be effective. To offset the impacts of increasing temperatures, Rezaei et al. (2015) suggested that cultural practices to create changes in phenological development for winter wheat in Germany would prevent exposure to high temperature events at anthesis; 
however, this change in phenological development would not alleviate the potential impacts of exposure to high temperatures on grain yield caused by shortening the grain-filling period.

Productivity of agricultural systems is the most used indicator of climate impacts, and in the current literature, there has been the utilization of the yield gap concept to evaluate climate and soil effects (Licker et al. 2010; Egli and Hatfield 2014a, b; van Brussel et al. 2015; Hatfield et al. 2018). This approach allows for a quantitative assessment of the ability of the crop to achieve its potential yield and the inability of closing the yield gap is ascribed to climatic stress.

Crop production systems respond to the weather conditions within a growing season and over time show responses to changes in the climate (Ray et al. 2015). Crop yields are one of the most utilized indicators of the impact of weather during the growing season, and county, state, and national yields have been extensively used to evaluate weather effects through statistical and simulation models. An example of statistical analysis approaches are provided in Runge (1968), Muchow et al. (1990), Lobell (2007), Lobell and Field (2007), and Hatfield et al. (2011) in which different parameters, e.g., temperature, precipitation, or solar radiation, have been related to the variation in crop yield among years. The use of simulation models to assess future effects of projected climate has been reported in Lobell et al. (2006) and Hatfield et al. (2011), and there are ample references detailing the utility of different methods.

Indicators of climate impacts on agriculture are available from existing databases assembled by the USDA National Agriculture Statistics Services (www.nass.usda.gov) with weekly crop condition and progress for major commodities, in comparison to the previous 4 years, and county level yields at the end of the crop season. An example of the crop progress chart is shown in Fig. 2 for Iowa comparing the 2017 corn growing season with previous seasons. These records offer a comprehensive database for the analysis of climate effects showing the effect of climate changes on planting dates and phenological development. A complement to these databases is the planted and harvested area for each county allowing for a direct determination of shifts in crop distribution across the USA. The area harvested and the yield per area provide a direct measure of total productivity and potential stocks of grain, forage, feed, fuel, and fiber. Phenological development of plants around the world has provided an indication of the change in the growing season and in particular the date of the first leaf or flower of indicator species.

Variation in production per area and total production for different commodities in response to seasonal weather provides an indication of the trend in yields. The research need is to develop improved relationships for different crops to quantify what amount of climate stress causes a certain degree of production loss. Examples of the change in production for maize, rice, wheat, and soybean are shown in Fig. 3. These data are shown since 1950 since that is considered the modern technological era in agriculture with the introduction of improved genetics, commercial fertilizers, and pesticides. Coupled with these trends in production which details the large variation in production among years due to the weather variation is the deviation of the production relative to the trend line for these same grains (Fig. 4). This was obtained by fitting a regression line through the yields and then subtracting the yields from the trend line to obtain the percentage deviation in yields. Deviations from the trend line show that we continue to have large deviations among years. This type of analysis allows for the identification of the impact of extreme climatic events, e.g., drought in 1988 and 2012, floods in 1993 (Fig. 4). These types of analyses could be completed for all of these crops plus other commodities to quantify the effects of a changing climate. 

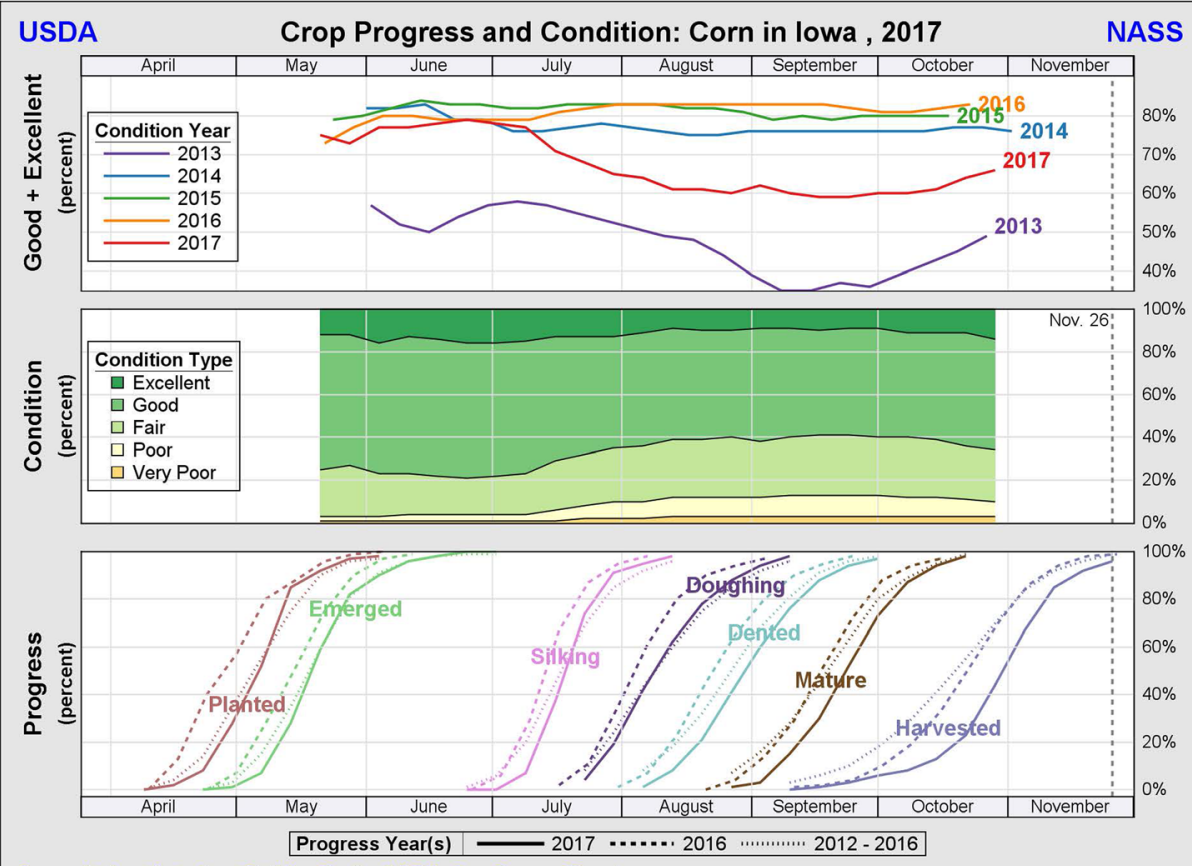

Source: National Agricultural Statistics Service (NASS), Crop Progress Report

Fig. 2 Crop progress and crop condition trajectory for Iowa in 2017 compared to the previous four growing seasons
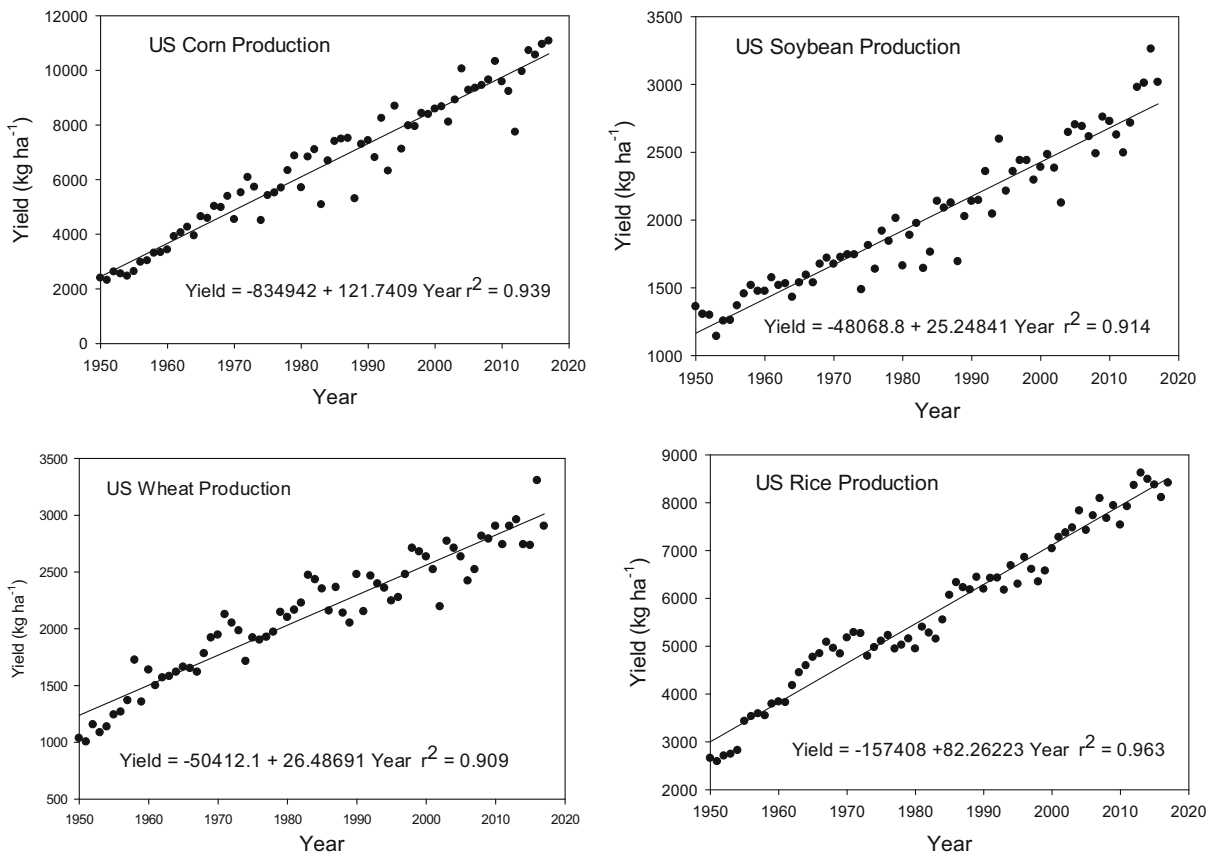

Fig. 3 Yield changes of corn, soybean, wheat, and rice for the USA for 1950-2017 with yield trend line for through the data. (Data accessed from nass.usda.gov, accessed on Feb. 16, 2018) 

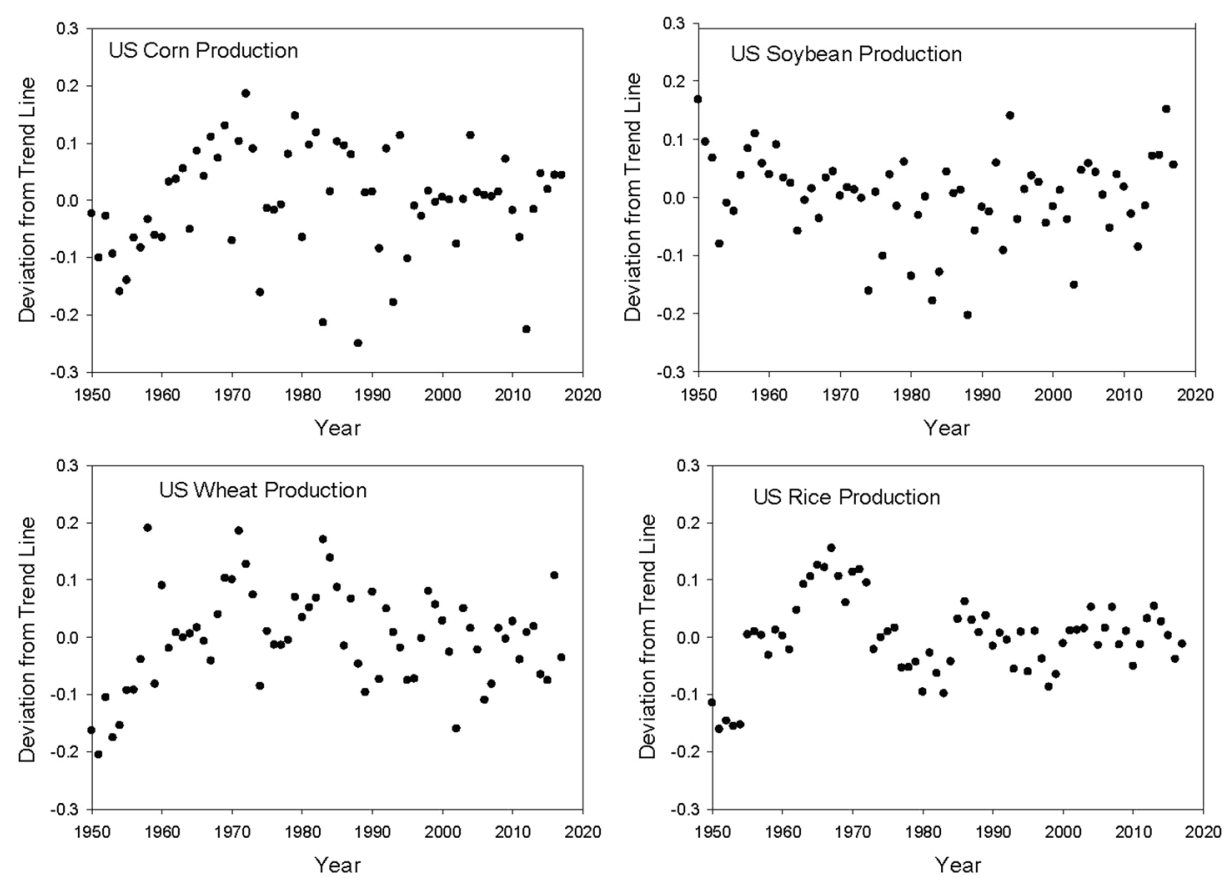

Fig. 4 Deviations of observed yield from the trend line for 1950-2017 for corn, soybean, wheat, and rice in the USA

Observed yield encompasses a number of important components of cropping systems, such as the effects of diseases, arthropod pests, and weeds, and the ability of farmers to effectively manage these biotic stressors. Biotic stressors represent an important wild card in the effects of climate change on agriculture, where cropping systems may need to adapt to newly invasive pest species or species that evolve to adapt to new environments. Developing indicators for climate change effects on biotic stressors is challenging due to the many interacting factors that influence their effects (Garrett et al. 2015). However, increasing emphases on the development and analysis of long-term data sets will facilitate future implementation of indicators for biotic stressors. For example, the use of global CABI records of pest and disease observations (Pasiecznik et al. 2005), even with associated challenges for interpretation (Garrett 2013), provides an important perspective on the spread of pests and pathogens under climate change (Bebber et al. 2013). Long-term data sets related to biotic stressors in the USA will help to partition the effects on yield of climate, crop genetics, and the effects of pests, diseases, and weeds.

\section{Research needs}

There are many potential indicators of climate impacts on agricultural systems (Table 1) that quantify the interactions among climatic variables and biological and economic parameters as depicted in the conceptual diagram (Fig. 1). Agricultural systems are composed of complex set of biological components coupled with the natural resources (soil, water, and air), and any robust indicator must consider how each of these factors responds to climate change. The 
indicators described in Table 1 have the potential to quantify the response of agriculture to climate change in both the near term and the long term. Illustrative of this process is the calendar assembled by Takle et al. (2014) for corn production in the Midwest, utilizing the decisions made by producers in response to weather conditions during the growing season and the long-term planning incorporating climate signals. Producers in the specialty crop and livestock sectors have indicated the need for indicators as to the impact of climate change and what changes need to be made in production systems to ensure both profitability and productivity. To further develop effective indicators relative to climate change, all indicators in Table 1 have the potential to increase the resilience of agriculture systems to climate change. The primary research need is to relate these indicators to climate signals in the near term (2020-2050) and long term (2050-2100). For example, there is a projection for chilling hours to decrease and an indicator would be flowering and productivity of perennial trees. The utility of this indicator would be transferred to perennial crop geneticists and production specialist to develop either new varieties with reduced chilling requirements or management practices to reduce this requirement. To achieve these goals will require the development of transdisciplinary teams to evaluate and perfect these indicators.

Open Access This article is distributed under the terms of the Creative Commons Attribution 4.0 International License (http://creativecommons.org/licenses/by/4.0/), which permits unrestricted use, distribution, and reproduction in any medium, provided you give appropriate credit to the original author(s) and the source, provide a link to the Creative Commons license, and indicate if changes were made.

\section{References}

Asseng S et al (2015) Rising temperatures reduce global wheat production. Nat Clim Chang 5:143-147

Baffaut C, Nearing MA, Nicks AD (1996) Impact of climate parameters on soil erosion using CLIGEN and WEPP. Trans. Am. Soc. of Agric Eng 39:447-457

Bebber DP, Ramotowski MAT, Gurr SJ (2013) Crop pests and pathogens move polewards in a warming world. Nat Clim Chang 3:985-988

Brown DJ, Hunt ER Jr, Izaurralde RC, Paustian KH, Rice CW, Schumaker BL, West TO (2010) Soil organic carbon change monitored over large areas. Eos 91:441-442

Egli DB, Hatfield JL (2014a) Yield gaps and yield relationships in central U.S. soybean production systems. Agron J 106:560-566

Egli DB, Hatfield JL (2014b) Yield gaps and yield relationships in central U.S. maize production systems. Agron J 106:2248-2256

Garbrecht JD, Nearing MA, Steiner JL, Zhang XJ, Nichols MH (2015) Can conservation trump impacts of climate change on soil erosion? An assessment from winter wheat cropland in the Southern Great Plains of the United States. Weather Clim Extremes 10:32-39

Garrett KA (2013) Big data insights into pest spread. Nat Clim Chang 3:955-957

Garrett, K.A., M. Nita, E.D. De Wolf, P.D. Esker, L. Gomez-Montano and A.H. Sparks, 2015. Plant pathogens as indicators of climate change. In: T. Letcher (Editor), Climate change: observed impacts on planet Earth, Second Edition. Elsevier, pp. 325-338

Gitelson AA, Peng Y, Masek JG, Rundquist DC, Verma S, Suyker A, Baker JM, Hatfield JL, Meyers T (2012) Remote estimation of crop gross primary production with Landsat data. Remote Sens Environ 121:404 414

Gitelson AA, Peng Y, Arkebauer TJ, Schepers J (2015) Productivity, absorbed photosynthetically active radiation, and light use efficiency in crops: implications for remote sensing of crop primary production. $\mathrm{J}$ Plant Physiol 177:100-109

Hatfield JL (2016) Increased temperatures have dramatic effects on growth and grain yield of three maize hybrids. Agric Environ Lett 1:150006. https://doi.org/10.2134/ael2015.10.0006

Hatfield JL, Prueger JH (2015) Temperature extremes: effects on plant growth and development. Weather Clim Extremes 10:4-10 
Hatfield JL, Wright-Morton L, Hall B (2018) Vulnerability of grain crops and croplands in the Midwest to climate variability and adaptation strategies. Clim Chang 146:263-275. https://doi.org/10.1007/s10584-0171997-X

Hatfield JL, Boote KJ, Kimball BA, Ziska LH, Izaurralde RC, Ort D, Thomson AM, Wolfe DW (2011) Climate impacts on agriculture: implications for crop production. Agron J 103:351-370

Innes PJ, Tan DKY, Van Ogtrop F, Amthor JS (2015) Effects of high-temperature episodes on wheat yields in New South Wales, Australia. Agric For Meteorol 208:95-107

Izaurralde RC, Thomson AM, Morgan JA, Fay PA, Polley HW, Hatfield JL (2011) Climate Impacts on Agriculture: Implications for Forage and Rangeland Production. Agron J 103:371-380

Kundzewicz, Z.W., L.J. Mata, N.W. Arnell, P. Döll, P. Kabat, B. Jiménez, K.A. Miller, T. Oki, Z. Sen and I.A. Shiklomanov, 2007: Freshwater resources and their management. Climate Change 2007: Impacts, Adaptation and Vulnerability. Contribution of Working Group II to the Fourth Assessment Report of the Intergovernmental Panel on Climate Change, M.L. Parry, O.F. Canziani, J.P. Palutikof, P.J. van der Linden and C.E. Hanson, Eds., Cambridge University Press, Cambridge, 173-210

Laza MRC, Sakai H, Cheng W, Tokida T, Peng S, Hasegawa T (2015) Differential response of rice plants to high night temperatures imposed at varying developmental phases. Agric For Meteorol 209-210:69-77

Licker R, Johnston M, Foley JA, Barford C, Kucharik CJ, Monfreda C, Ramankutty N (2010) Mind the gap: how do climate and agricultural management explain the 'yield gap' of croplands around the world? Glob Ecol Biogeogr 19:769-782

Lobell DB (2007) Changes in diurnal temperature and national cereal yields. Agric For Meteorol 145: $229-238$

Lobell DB, Field CB (2007) Global scale climate-crop yield relationships and the impacts of recent warming. Environ Res Lett 2:1-7

Lobell DB, Bala G, Bonfils C, and Duffy PB (2006) Potential bias of model projected greenhouse warming in irrigated regions. Geophysical Res Lett 33:L13709. https://doi.org/10.1029/2006GL026770

Mader TL (2012) Impact of environmental stress on feedlot cattle. Western Sect Am J Animal Soc 62:335-339

Mader TL, Johnson LJ, Gaughan JB (2010) A comprehensive index for assessing environmental stress in animals. J Anim Sci 88:2153-2165

Melillo, J.M., T.C. Richmond, and G.W. Yohe (eds.). 2014. Climate change impacts in the United States: the Third National Climate Assessment, U.S. Global Change Research Program, pp. 150-174. doi:https://oi. org/10.7930/J02Z13FR. http://nca2014.globalchange.gov/report

Muchow RC, Sinclair TR, Bennett JM (1990) Temperature and solar-radiation effects on potential maize yield across locations. Agron J 82:338-343

Nearing MA, Ascough LD, Laflen JM (1990) Sensitivity analysis of the WEPP hillslope profile erosion model. Trans Am Soc of Agric Eng 33:839-849

Nearing MA (2001) Potential changes in rainfall erosivity in the United States with climate change during the $21^{\text {st }}$ century. J Soil and Water Cons 56(3):229-232

Pasiecznik NM, Smith IM, Watson GW, Brunt AA, Ritchie B, Charles LMF (2005) CABI/EPPO distribution maps of plant pests and plant diseases and their important role in plant quarantine. EPPO Bulletin 35:1-7

Paul EA, Paustian K, Elliott ET, Cole CV (eds) (1997) Soil organic matter in temperate ecosystems: long-term experiments in North America. Lewis CRC Publishers, Boca Raton

Pruski FF, Nearing MA (2002) Runoff and soil loss responses to changes in precipitation: a computer simulation study. J Soil and Water Cons. 57(1):7-16

Ray, D.K., J.S. Gerber, G.K. MacDonald, and P.C. West. 2015. Climate variations explains a third of global yield variability. Nature Comm. 6:5989/DOI:https://doi.org/10.1038/ncomms6989

Renard KG, Freidmund JR (1994) Using monthly precipitation data to estimate the R-factor in the revised USLE. J Hydrol 157:287-306

Renard, K.G., G.R. Foster, G.A. Weesies, D.K. McCool, and D.C. Yoder. 1997. Predicting soil erosion by water-a guide to conservation planning with the revised universal soil loss equation (RUSLE). Agricultural Handbook No. 703, U.S. Government Printing Office, Washington, D.C.

Rezaei EE, Siebert S, Ewert F (2015) Intensity of heat stress in winter wheat-phenology compensates for the adverse effect of global warming. Environ Res Lett 10. https://doi.org/10.1088/1748-9326/10/2/024012

Runge ECA (1968) Effect of rainfall and temperature interactions during the growing season on corn yield. Agron J 60:503-507

Schlenker W, Roberts MJ (2009) Nonlinear temperature effects indicate severe damages to U.S. crop yields under climate change. Proc Natl Acad Sci U S A 106:15594-15598

Soil and Water Conservations Society (2003) Soil Erosion and runoff from cropland report from the USA. Soil and Water Conservation Society, Ankeny, IA, p 63

St. Pierre NR, Cobanov B, Schnitkey G (2003) Economic losses from heat stress by US livestock industries. J Dairy Sci 86:E52-E77 
Tack J, Barkley A, Nalley LL (2015) Effect of warming temperatures on US wheat yields. Proc Natl Acad Sci U S A 112:6931-6936

Takle, E.S., C.J. Anderson, J. Andresen, J. Angel, R.W. Elmore, B.M. Gramig, P. Guinan, S. Hilberg, D. Kluck, R. Massey, D. Niyogi, J.M. Schneider, M.D. Shulski, D. Todey, and M. Widhalm. 2014. Climate forecasts for corn producer decision making. Earth Interactions 18: DOI.1175/2013EI000541.1

van Bussel LGJ, Grassini P, Van Wart J, Wolf J, Claessens L, Yang H, Boogaard H, de Groot H, Saito K, Cassman KG, van Ittersum MK (2015) From field to atlas: upscaling of location-specific yield gap estimates. Field Crop Res 177:98-108

Walthall CL, Hatfield J, Backlund P, Lengnick L, Marshall E, Walsh M, Adkins S, Aillery M, Ainsworth EA, Ammann C, Anderson CJ, Bartomeus I, Baumgard LH, Booker F, Bradley B, Blumenthal DM, Bunce J, Burkey K, Dabney SM, Delgado JA, Dukes J, Funk A, Garrett K, Glenn M, Grantz DA, Goodrich D, Hu S, Izaurralde RC, Jones RAC, Kim S-H, Leaky ADB, Lewers K, Mader TL, McClung A, Morgan J, Muth DJ, Nearing M, Oosterhuis DM, Ort D, Parmesan C, Pettigrew WT, Polley W, Rader R, Rice C, Rivington M, Rosskopf E, Salas WA, Sollenberger LE, Srygley R, Stöckle C, Takle ES, Timlin D, White JW, Winfree R, Wright-Morton L, Ziska LH (2012) Climate change and agriculture in the United States: effects and adaptation. USDA technical bulletin 1935, Washington, DC, p 186

Williams J, Nearing MA, Nicks A, Skidmore E, Valentine C, King K, Savabi R (1996) Using soil erosion models for global change studies. J Soil and Water Conserv 51(5):381-385

Wischmeier WH, Smith DD (1978) Predicting rainfall erosion losses - a guide to conservation planning. U.S. Department of Agriculture, Agriculture Handbook No. 537 